INTERNATIONAL DESIGN CONFERENCE - DESIGN 2018

https://doi.org/10.21278/idc.2018.0208

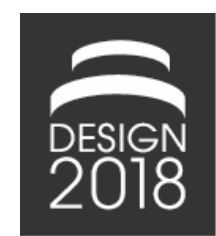

\title{
PRODUCT VARIETY AND VARIETY IN PRODUCTION
}

\author{
J. Landahl and H. Johannesson
}

\begin{abstract}
Variety traditionally denotes products that serve a wide range of customer needs. However, variety in production exists too. Like products, production processes and production resources may also embody variety to serve the production fulfillment of a product variety. In this paper, product variety and variety in production are described and contrasted through a literature review. The aim is to serve the engineering design community with an elevated perspective of variety in production and its relation to product variety.
\end{abstract}

Keywords: variety, variant management, production design, product design

\section{Introduction}

Variety is a common concept that describes a number or range of things of the same general class that are distinct in character or quality. A thing is an object that one need not, cannot, or does not wish to give a specific name to (Oxford Dictionaries, 2017).

The common industrial use of variety is to describe the immense number of product variants that can meet (1) a wide range of customer needs; the product variety, and (2) different market segments; the product families. There are various industries affected by the high number of variants that are driven by the aim to meet a wide range of specific customer needs. An example that proves the magnitude of variety in the automotive industry is from the BMW Group as they reached an astonishing number of $10^{17}$ variants of their 7 Series cars (Hu et al., 2008). Managing such high product variety is a complex task (ElMaraghy et al., 2012), and several challenges related to achieving efficient product variety management have been identified (ElMaraghy et al., 2013).

In industry, manufacturers constantly battle to efficiently develop and produce a variety of products with differentiated configuration and performance while ensuring that each variant can be produced utilizing a selection of production resources. To ensure functionality and quality of the product variants, as well as to predict system behavior, products and production systems can be modeled. While product modeling primarily aims to verify the fulfillment of the customer needs and reach the adequate product performance and quality, production modeling aims to coordinate production resources and processes and satisfy the production fulfillment of the products at specified time, cost and quality.

The sequential approach "product performance first and producibility second" is commonplace. The product performance is typically optimized to absurdum before including the production aspects. If, at this late stage, the performance-optimized design proves to be non-producible, modifications are required that can increase cost (Rush and Roy, 2000) and compromise the product performance. Although there is a common notion that companies can gain efficiency by integrating product and production development, for example through concurrent engineering (Prasad, 1996) and Design for 
Manufacturing (DfM) (Boothroyd, 1994), it is still difficult for design engineers to include production aspects during the conceptual product design stages.

To support engineers from both product design and production to develop a producible product variety, mutual product-production models that support the conceptual product design stages are needed (Wang et al., 2002), and especially them concerning variety. Currently, there is a void of research that clearly describes and explains variety in production like product variety, which may hinder the creation of proper support.

In this study, product variety and variety in production are viewed through the same eyeglasses in order to provide new knowledge related to the product-production variety interplay. The aim of this study is to serve the engineering design community with an elevated perspective of variety in production and its relation to product variety. The underlying concepts are described and explained by approaching three research questions (RQs): RQ1: On a general level, how can product variety and variety in production be described? RQ2: How do product variety and variety in production relate? RQ3: Based on the existing research, what is the relative research trend of product variety and variety in production?

\section{Literature review}

The literature review is structured following the three main classifications shown in Figure 1: (1) Variety, (2) Family, and (3) Architecture. The concept of Technical System serves as a general class of these three classifications: Variety of Technical Systems, Family of Technical Systems, and Architecture of Technical Systems. Moreover, we distinguish between product variety and variety in production by studying concepts akin to the two.

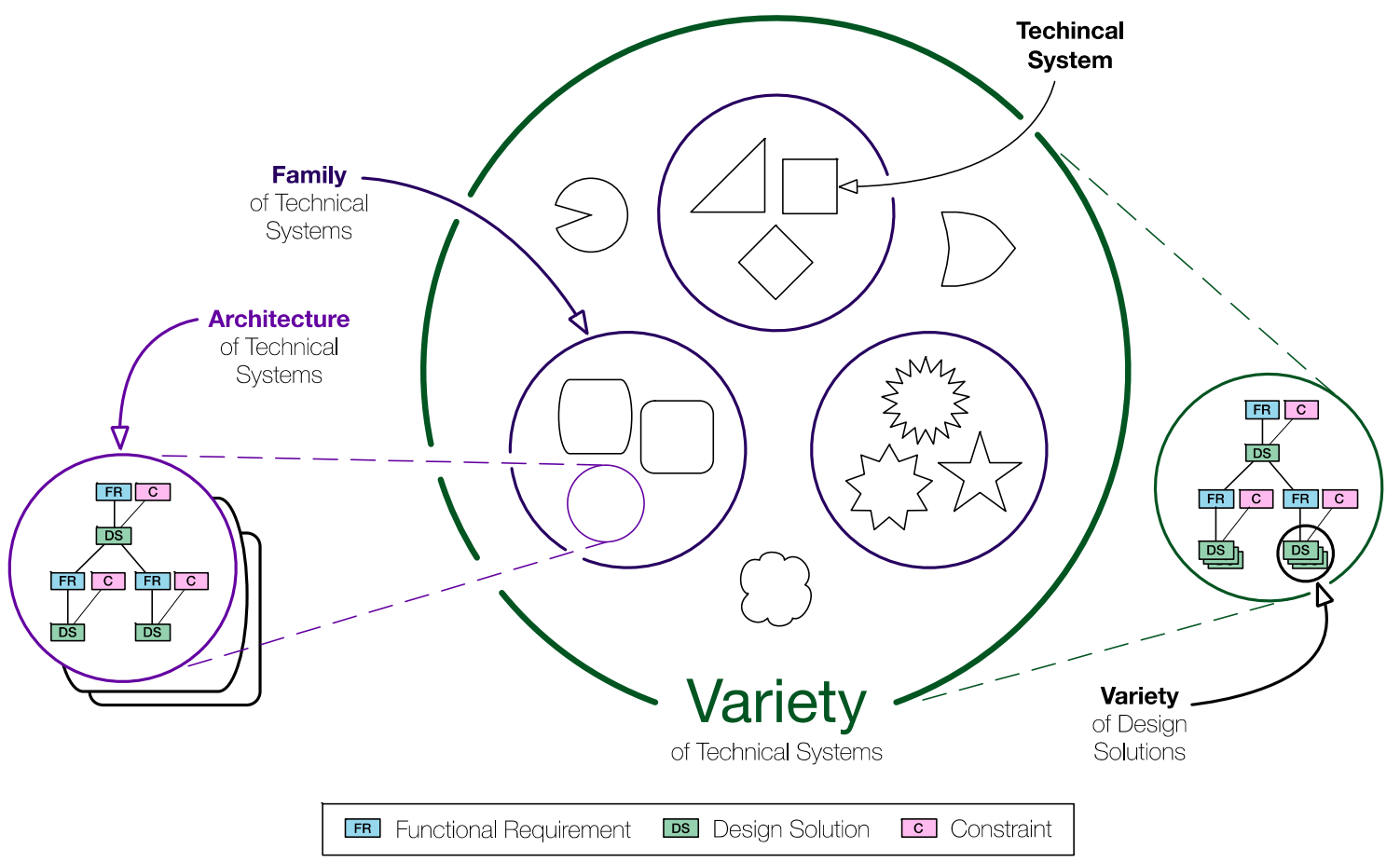

Figure 1. A classification: variety of, family of, and architecture of technical systems

\subsection{Technical systems}

Hubka and Eder (1988) introduced the theory of technical systems (TTS) to support design engineers to better understand artifacts and processes related to technical systems. By adding the descriptive word 
technical onto the definition of a system from Oxford Dictionaries (2017) a technical system is a set of technical things working together as parts of a mechanism or an interconnecting network; a complex whole. Concerning product variety and variety in production in this study, the technical systems are represented as products, production processes, or production resources.

\subsection{Variety of, and family of technical systems}

Up until now, a vast body of knowledge related to product variety exists. Several practical concepts have been developed to support product variety management, such as various forms of standardization (Ulrich, 1995), modularization (Erixon et al., 1996), product family design (Erens, 1996), and product platform development (Wheelwright and Clark, 1992; Meyer and Lehnerd, 1997; Sawhney, 1998; Jiao et al., 2000; Salvador et al., 2002; Halman et al., 2003; Simpson et al., 2006; Jiao et al., 2007a; Alizon et al., 2007; Krause and Eilmus, 2011; Levandowski et al., 2013; Johannesson et al., 2017; Meyer et al., 2017). Although variety traditionally concerns products through the eyeglasses of marketing, engineering, and distribution, variety in production exist too. Several concepts akin to variety in production have been proposed: such as Cellular Manufacturing (CM) (Choobineh, 1988), Flexible Manufacturing Systems (FMS) (Browne et al., 1984; ElMaraghy, 2005), Modular Production Systems (MPS) (Rogers and Bottaci, 1997), Reconfigurable Manufacturing Systems (RMS) (Koren et al., 1999; Koren et al., 2016), Agile Manufacturing Systems (AMS) (Gunasekaran, 1999), Generic-Bill-of-Materials-and-Operations (GBOMO) (Jiao et al., 2000), process platforms (Jiao et al., 2007a), manufacturing platforms (Michaelis and Johannesson, 2011).

Based on the definition of product platforms by Robertson and Ulrich (1998), a platform of technical systems can be defined as a collection of assets that are shared and reused among a set of technical systems. A variety of technical systems can relate to each other in character or quality, like a family. A family is a common concept to describe a group of related things (Oxford Dictionaries, 2017). Because a technical system can be denoted a product, a production process, or a production resource, a family of technical systems can refer to a family of products, a family of production processes, or a family of production resources. Especially, there are several publications related product variety and product family design, for example Erens (1996), Simpson (1998), and Jiao et al. (2007b). Also integrated product-production approaches have been developed, such as the design of product families with the influence of production resource constraints (Kimura and Nielsen, 2005), and approaches for the co-development of products and production systems (Bryan et al., 2007; Tolio et al., 2010; ElMaraghy and Abbas, 2015). However, the family class is seldom used to describe a group of related production processes or production resources. On a lower level of abstraction, Du et al. (2001) consider the product family design by regarding the architecture.

\subsection{Architecture of technical systems}

An architecture postulates the complex or carefully designed structure of something (Oxford Dictionaries, 2017). In this study, the definition regards the architecture of the following technical systems: products, production processes, and production resources.

The product architecture is defined as "the scheme by which the function of a product is allocated to physical components" (Ulrich, 1995). This scheme includes the arrangement of functional elements, mapping from functional elements to physical components, and the specification of interfaces. Several methods have been proposed to model the architecture of a product, such as the creation of the FunctionMeans (F-M) tree (Andreasen, 1980) and Enhanced Function-Means (EF-M) tree (Schachinger and Johannesson, 2000) that regards the hierarchical modeling of Functional Requirements (FRs), Design Solutions (DSs), Constraints (Cs), and their relations. The architecture of a variety of products can be encompassed in on single EF-M tree by modeling a variety of DSs solving the same FR (Berglund and Claesson, 2005). For example, 'FR: convert energy into mechanical motion' can be solved by 'DS1: gasoline combustion engine', 'DS2: diesel combustion engine', or 'DS3: electric engine'. This modular bandwidth can be used to develop and configure several product variants concurrently, discussed in for example (Levandowski et al., 2015). 
Wheelwright and Clark (1992) emphasize that production requirements and capabilities need to be combined with design requirements to lay down the product architecture. In simple terms, a conventional product (e.g. a gasoline combustion engine) and a production machine (e.g. an industrial robot) are alike; however, in fact they differ in one fundamental aspect: While the gasoline combustion engine is intended to fulfill the same function throughout its lifecycle, the industrial robot need to serve multi-functionality and be reconfigurable to enable the insertion of additional tools when needed (Koren et al., 2016). For example, the industrial robot needs to serve the production fulfillment of different types and sizes among the product variety that may change over time (Qiao and Weiss, 2016). Therefore, to provide a decent basis for product-production modeling, the concept of architecture needs to be generalized to serve different sub-classes of technical systems. A general definition of an architecture, i.e. system architecture, is provided by Crawley et al. (2004): "system architecture is an abstract description of the entities of a system and the relationships between those entities."

To organize and coordinate the design activities of complex systems among several design teams, the concept of modularization was introduced. Modularization focus on "building a complex product or process from smaller subsystems that can be designed independently yet function together as a whole." (Baldwin and Clark, 1997). Modularization has been a fundamental concept of product family design, product platform development, as well as similar concepts in production such as the Modular Production Systems (MPS) (Rogers and Bottaci, 1997) and the Reconfigurable Manufacturing Systems (RMS) (Koren et al., 1999). During the production, the modularity of the MPS and the RMS is pivotal to allow quick changeover to serve the production fulfillment of many different product variants among a product variety, i.e. the convertibility of the RMS (Mehrabi et al., 2000).

\section{Research method}

To answer RQ1 and RQ2, a literature review on variety from the perspective of product and production was conducted. Concepts akin to the two types of variety were identified. The main result of RQ1 is a model that represents both product variety and variety in production. RQ2 is answered through a qualitative analysis and a table that show the relation of the akin concepts and the types of variety is presented.

To answer RQ3, a systematic search in SCOPUS ${ }^{\circledR}$ was conducted: (1) during a literature review, several concepts akin to product variety and variety in production were identified, (2) keywords related to these concepts were categorized according to general, excluded, and specific keywords (see Table 1), (3) based on the keywords two distinctive search strings were created in SCOPUS ${ }^{\circledR}$ (see Table 2), and finally (4) data representing the number of publications on product variety and variety in production, published during the years 1970-2016, was collected, visualized (see Figure 4), and then analyzed.

Table 1. Keywords categorized according to: specific, excluding, and general

\begin{tabular}{|l|l|l|l|}
\hline & $\begin{array}{l}\text { Specific } \\
\text { keywords }\end{array}$ & $\begin{array}{l}\text { Excluded } \\
\text { keywords }\end{array}$ & $\begin{array}{l}\text { General } \\
\text { keywords }\end{array}$ \\
\hline Product Variety & $\begin{array}{l}\text { + product platform* } \\
\text { + product famil* } \\
\text { + part famil* } \\
\text { + product variant* }\end{array}$ & + variet* \\
\hline Variety in Production & $\begin{array}{l}\text { + cellular manufacturing system* } \\
\text { + flexible manufacturing system* } \\
\text { + modular production system* } \\
\text { + reconfigurable manufacturing system* } \\
\text { + agile manufacturing system* } \\
\text { + manufacturing platform* } \\
\text { + production platform* }\end{array}$ & $\begin{array}{l}\text { - product design } \\
\text { - product development } \\
\text { - product variety }\end{array}$ & \\
\hline
\end{tabular}


Table 2. The two search strings applied in SCOPUS®

\begin{tabular}{|c|c|}
\hline & SCOPUS® Search String \\
\hline $\begin{array}{l}\text { Product } \\
\text { Variety }\end{array}$ & 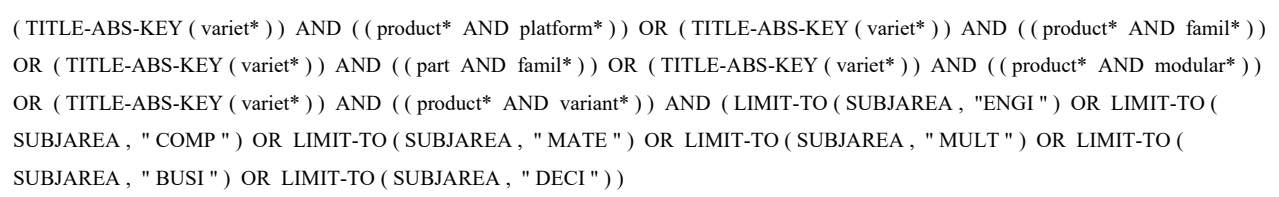 \\
\hline $\begin{array}{l}\text { Variety in } \\
\text { Production }\end{array}$ & 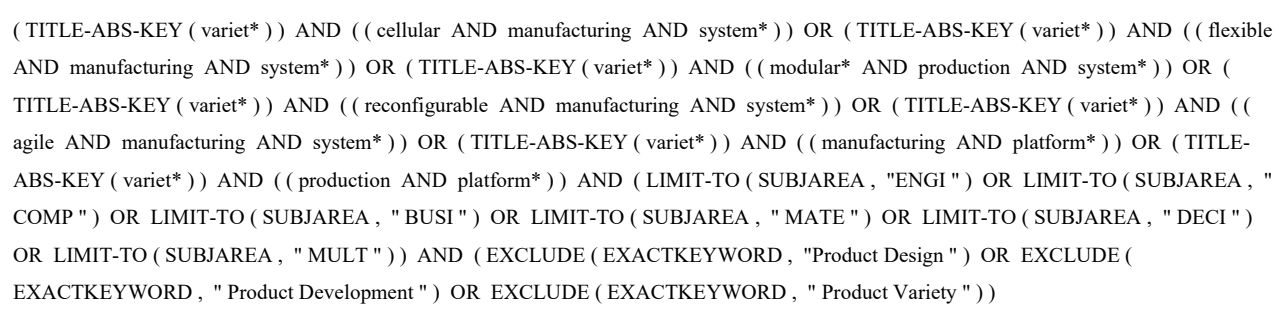 \\
\hline
\end{tabular}

\section{Results}

Fundamentally, this research regards technical systems as a general class of variety. More specifically in this study, product and production are regarded as two separate classes. The sub-sections of the results largely follows the structure of the research questions posed: Sub-section 4.1 refers to RQ1, 4.2 refers to RQ2, and 4.3 refers to RQ3.

\subsection{Descriptions of product variety and variety in production}

Based on the literature review conducted in this study, a model that represents product variety and variety in production was created. In Figure 2, product variety, variety in production, and their interplay are illustrated, and descriptions of the concepts are reported. These descriptions aim to support the knowledge about the product-production variety interplay.

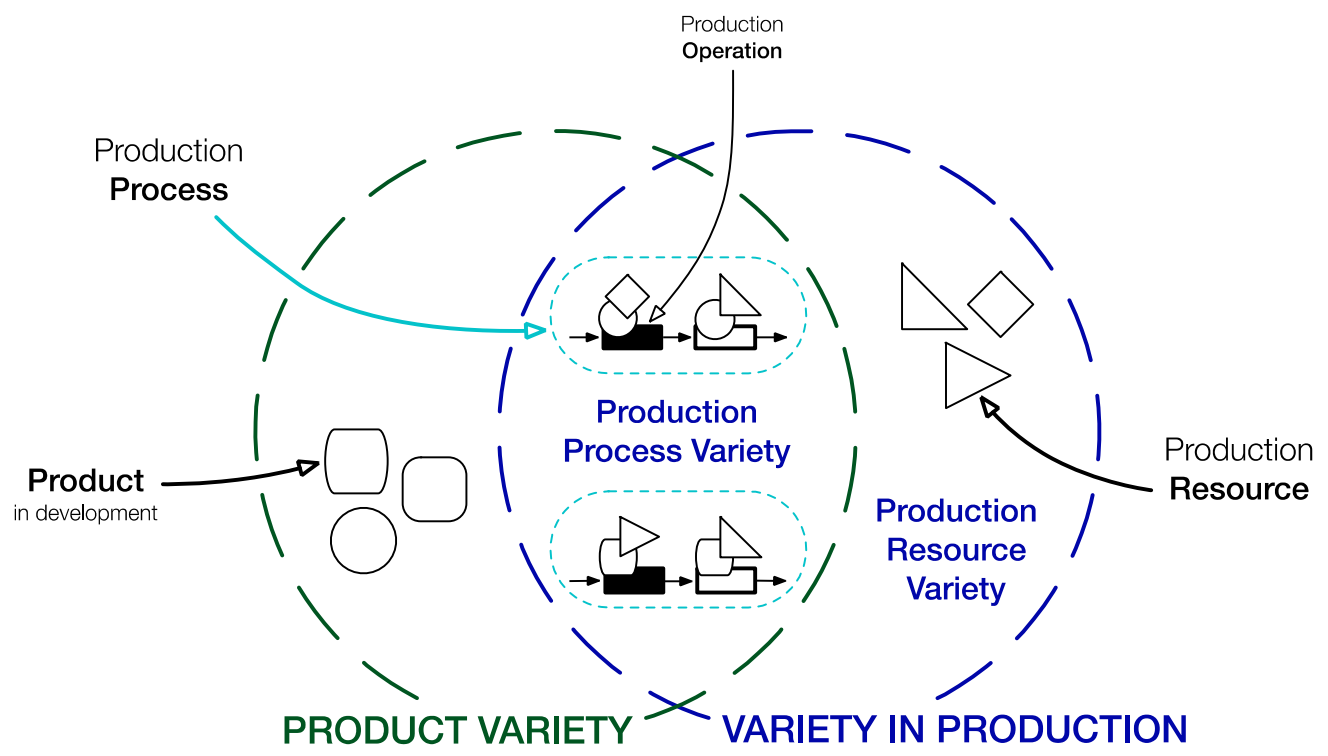

Figure 2. Product variety and variety in production

In this paper, product variety is described as a set of product variants that aims to satisfy a wide range of customer needs. In modeling of the product architecture, product variety can be exemplified by a variety of design solutions that fulfills a functional requirement, for example 'FR1: convert energy into 
mechanical motion' can be solved by either 'DS1a: gasoline combustion engine', 'DS1b: diesel combustion engine', or 'DSIc: electric engine' (see left part of Figure 3).

Variety in production is a broader term than product variety. In this paper, variety in production is decomposed into two sub-classes: production process variety and production resource variety, that collectively serves the production fulfillment of the product variants among the product variety. Production process variety is described as a set of production processes aimed to serve the sequence of production operations required to reach the desired refinement of a product variety. An example of production resource variety is to solve the function 'FR1: join parts' by either of the operations 'OPIa: glueing', or 'OP1b: welding' (see mid part of Figure 3). Production resource variety is described as $a$ set of production resources, each with its certain function and performance, aimed to support certain refinement of a product variety. Production resource variety can be exemplified by a variety of design solutions that fulfills a functional requirement, for example 'FR1: generate ray of energy' can be solved by either 'DS1a: TIG weld head', 'DS1b: Laser Arc weld head', or 'DS1c: Electron Beam weld head' (see right part of Figure 3). To show that there are interdependencies across product variety, production process variety and production resource variety, arbitrary relations are shown in Figure 3. Note: for more in-depth reasoning of these relations, read Landahl et al. (2017).

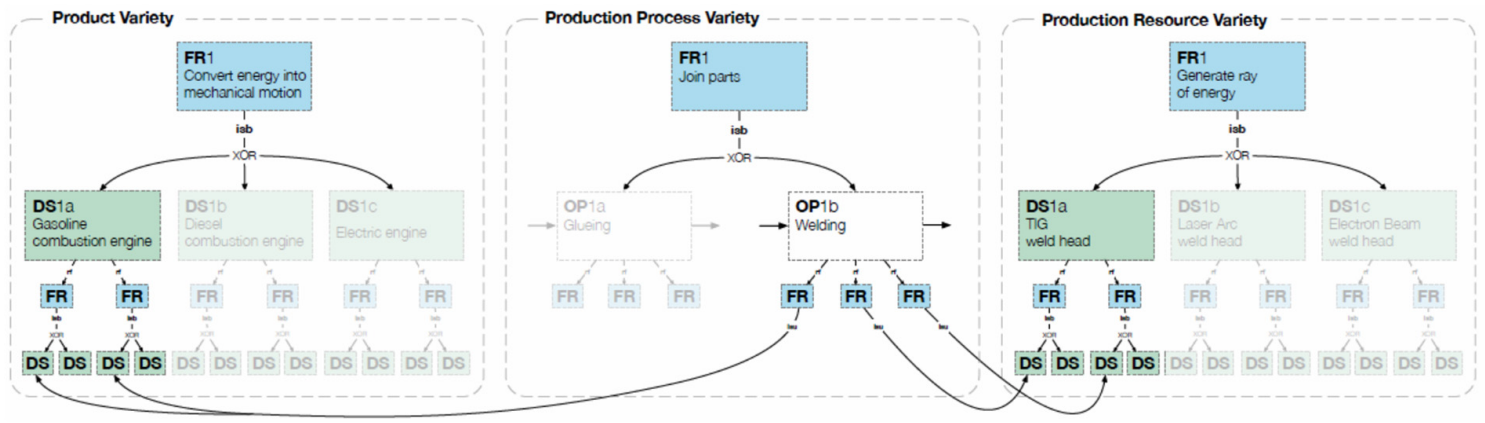

Figure 3. The variety of technical systems represented as three architecture models that are interconnected (some parts are faded and omitted due to pedagogical reasons)

\subsection{Relations of the concepts akin to product variety and variety in production}

To study and contrast product variety and variety in production, and specifically their relation to the identified concepts akin to the two, a qualitative analysis was conducted. In Table 3, the relation map of each concept akin to product variety and variety in production is shown respectively. Each relation is represented in a cell of Table 3. To distinguish an akin concept and its core focus of either product variety or variety in production, it is labeled primary or secondary. To clarify the relation, it is also labeled explicit or implicit followed by a short description. An explicit relation in this study is described as a clear relation, leaving no room for doubt that the relation exists, while the implicit relation in this study is described as a relation that is not directly expressed.

Table 3. Product variety, variety in production, and how akin concepts are related (primary or secondary, and explicit or implicit) to the two respectively

\begin{tabular}{|c|c|c|c|}
\hline \multirow[b]{2}{*}{ Akin concepts } & \multirow[b]{2}{*}{ Product Variety } & \multicolumn{2}{|c|}{ Variety in Production } \\
\hline & & $\begin{array}{c}\text { Production Process } \\
\text { Variety }\end{array}$ & $\begin{array}{c}\text { Production Resource } \\
\text { Variety }\end{array}$ \\
\hline $\begin{array}{r}\text { Product Variant } \\
\text { Main reference: } \\
\text { (Ericsson and Erixon, 1999) }\end{array}$ & $\begin{array}{l}\text { Primary Implicit } \\
\text { A product variant is an } \\
\text { instance of the product } \\
\text { variety. }\end{array}$ & $\begin{array}{l}\text { Secondary Implicit } \\
\text { A sole variant can follow } \\
\text { the same production } \\
\text { process. }\end{array}$ & $\begin{array}{l}\text { Secondary Implicit } \\
\text { A sole variant can utilize the } \\
\text { same production resources. }\end{array}$ \\
\hline $\begin{array}{r}\text { Product } \\
\text { Modularization } \\
\text { Main reference: }\end{array}$ & $\begin{array}{l}\text { Primary Explicit } \\
\text { Standardized interfaces } \\
\text { serve interchangeability } \\
\text { and reuse of modules }\end{array}$ & $\begin{array}{l}\text { Secondary Implicit } \\
\text { Focuses on reducing } \\
\text { variety of production } \\
\text { processes. }\end{array}$ & $\begin{array}{l}\text { Secondary Implicit } \\
\text { Focuses on maximizing the } \\
\text { utilization of expensive }\end{array}$ \\
\hline
\end{tabular}




\begin{tabular}{|c|c|c|c|}
\hline (Erixon et al., 1996) & $\begin{array}{l}\text { among a family of } \\
\text { products. }\end{array}$ & & $\begin{array}{l}\text { production machines and } \\
\text { tools. }\end{array}$ \\
\hline $\begin{array}{r}\text { Product Platform } \\
\text { Main reference: } \\
\text { (Robertson and Ulrich, 1998) } \\
\text { and } \\
\text { Product Family } \\
\text { Main reference: } \\
\text { (Erens, 1996) }\end{array}$ & $\begin{array}{l}\text { Primary Explicit } \\
\text { Focuses on reuse of assets } \\
\text { among a variety (family) of } \\
\text { products by finding } \\
\text { commonalities among the } \\
\text { variants and still achieve } \\
\text { product distinctiveness. }\end{array}$ & $\begin{array}{l}\text { Secondary Implicit } \\
\text { Focuses on reducing the } \\
\text { variety of production } \\
\text { processes used to } \\
\text { produce the unique } \\
\text { parts/modules. }\end{array}$ & $\begin{array}{l}\text { Secondary Implicit } \\
\text { Focuses on maximizing the } \\
\text { utilization of expensive } \\
\text { production machines and } \\
\text { tools and reduce the number } \\
\text { of production resources that } \\
\text { are utilized to produce } \\
\text { unique parts/modules. }\end{array}$ \\
\hline $\begin{array}{r}\text { Cellular } \\
\text { Manufacturing } \\
\text { Systems (CMS) } \\
\text { Main reference: } \\
\text { (Choobineh, 1988) } \\
\end{array}$ & $\begin{array}{l}\text { Secondary Explicit } \\
\text { CMS aims to support a low } \\
\text { number of variants among } \\
\text { a product family. }\end{array}$ & $\begin{array}{l}\text { Primary Explicit } \\
\text { Focuses on allowing a } \\
\text { restricted production } \\
\text { process variety within } \\
\text { manufacturing cells. }\end{array}$ & $\begin{array}{l}\text { Primary Explicit } \\
\text { Focuses on allowing a } \\
\text { restricted production } \\
\text { resource variety within } \\
\text { manufacturing cells. }\end{array}$ \\
\hline $\begin{array}{r}\text { Flexible } \\
\text { Manufacturing } \\
\text { Systems (FMS) } \\
\text { Main references: } \\
\text { (Browne et al., 1984; } \\
\text { ElMaraghy, 2005) } \\
\end{array}$ & $\begin{array}{l}\text { Secondary Explicit } \\
\text { FMS aims to support a } \\
\text { medium number of } \\
\text { variants among a product } \\
\text { family. }\end{array}$ & $\begin{array}{l}\text { Primary Explicit } \\
\text { Focuses on flexibility of } \\
\text { production processes to } \\
\text { serve pre-defined } \\
\text { product families that can } \\
\text { change over time. }\end{array}$ & $\begin{array}{l}\text { Primary Implicit } \\
\text { Focuses on flexibility of } \\
\text { production resources with a } \\
\text { fixed machine structure to } \\
\text { serve product families that } \\
\text { can change over time. }\end{array}$ \\
\hline $\begin{array}{r}\text { Modular } \\
\text { Production } \\
\text { Systems (MPS) } \\
\text { Main reference: } \\
\text { (Rogers and Bottaci, 1997) }\end{array}$ & $\begin{array}{l}\text { Secondary Implicit } \\
\text { The product variety may } \\
\text { determine the variety in } \\
\text { production. }\end{array}$ & $\begin{array}{l}\text { Primary Implicit } \\
\text { Focuses on adapting the } \\
\text { production processes to } \\
\text { serve the production } \\
\text { fulfillment of a product } \\
\text { variety. }\end{array}$ & $\begin{array}{l}\text { Primary Explicit } \\
\text { Focuses on the } \\
\text { modularization of machines } \\
\text { and tools to rapidly } \\
\text { configure and reconfigure } \\
\text { the production systems. }\end{array}$ \\
\hline $\begin{array}{r}\text { Agile } \\
\text { Manufacturing } \\
\text { Systems (AMS) } \\
\text { Main reference: (Gunasekaran, } \\
\text { 1999) }\end{array}$ & $\begin{array}{l}\text { Secondary Implicit } \\
\text { The product variety may } \\
\text { determine the variety in } \\
\text { production. }\end{array}$ & $\begin{array}{l}\text { Primary Explicit } \\
\text { Focuses on the rapid } \\
\text { changeover from } \\
\text { producing one product to } \\
\text { producing another. }\end{array}$ & $\begin{array}{l}\text { Primary Explicit } \\
\text { Focuses on the rapid } \\
\text { changeover from producing } \\
\text { one product to producing a } \\
\text { different product. }\end{array}$ \\
\hline $\begin{array}{r}\text { Reconfigurable } \\
\text { Manufacturing } \\
\text { Systems (RMS) } \\
\text { Main reference: } \\
\text { (Koren et al., 1999) }\end{array}$ & $\begin{array}{l}\text { Secondary Implicit } \\
\text { The product variety may } \\
\text { determine the variety in } \\
\text { production. }\end{array}$ & $\begin{array}{l}\text { Primary Implicit } \\
\text { Focuses on swiftly } \\
\text { adapting the production } \\
\text { processes to serve the } \\
\text { production fulfillment of } \\
\text { the current and future } \\
\text { product variety. }\end{array}$ & $\begin{array}{l}\text { Primary Explicit } \\
\text { Focuses on the convertibility } \\
\text { of the parts of the machines } \\
\text { and tools to swiftly adapt the } \\
\text { production resources to } \\
\text { serve the production } \\
\text { fulfillment of the current and } \\
\text { future product variety. }\end{array}$ \\
\hline $\begin{array}{r}\text { Process } \\
\text { Platform } \\
\text { Main reference: } \\
\text { (Jiao et al., 2007a) }\end{array}$ & $\begin{array}{l}\text { Secondary Explicit } \\
\text { The product variety } \\
\text { determines the variety in } \\
\text { production. }\end{array}$ & $\begin{array}{l}\text { Primary Explicit } \\
\text { Focuses on reuse of } \\
\text { production operations by } \\
\text { finding commonalities } \\
\text { among a variety of } \\
\text { production process } \\
\text { variants. }\end{array}$ & $\begin{array}{l}\text { Primary Implicit } \\
\text { The product variety and } \\
\text { production process variety } \\
\text { may affect the production } \\
\text { resource variety. }\end{array}$ \\
\hline $\begin{array}{r}\text { Manufacturing } \\
\text { (Production) } \\
\text { Platform } \\
\text { Main reference: } \\
\text { (Michaelis and Johannesson, } \\
2011 \text { ) }\end{array}$ & $\begin{array}{l}\text { Secondary Implicit } \\
\text { The product variety is not } \\
\text { necessarily a prerequisite } \\
\text { for the manufacturing } \\
\text { platform as a } \\
\text { manufacturing system can } \\
\text { be developed separately } \\
\text { from a product variety. }\end{array}$ & $\begin{array}{l}\text { Primary Implicit } \\
\text { Focuses on reuse of } \\
\text { production processes by } \\
\text { finding commonalities } \\
\text { among a variety of } \\
\text { production processes. }\end{array}$ & $\begin{array}{l}\text { Primary Explicit } \\
\text { Focuses on reuse of modules } \\
\text { among a variety of } \\
\text { production resources by } \\
\text { finding commonalities } \\
\text { among the production } \\
\text { resources (machines and } \\
\text { tools). }\end{array}$ \\
\hline
\end{tabular}




\subsection{Research trend on product variety and variety in production}

To study the research trend on the identified concepts akin to product variety and variety in production respectively, a systematic search in SCOPUS ${ }^{\circledR}$ was conducted. The akin concepts (see Table 3 ) was used to determine a set of keywords (see Table 1) and two distinctive search strings was created (see Table 2). In Figure 4, the number of publications published from 1970 until 2016 related to product variety and variety in production respectively are shown. Two intriguing characteristics can be observed: (1) the parallelism of the two concepts until year 2006, (2) the relative increase of publications concerning variety in production (compared with product variety) until year 2015. Bear in mind a general increase of publications in Scopus over time; therefore, primarily the relative increase of publications is of interest.

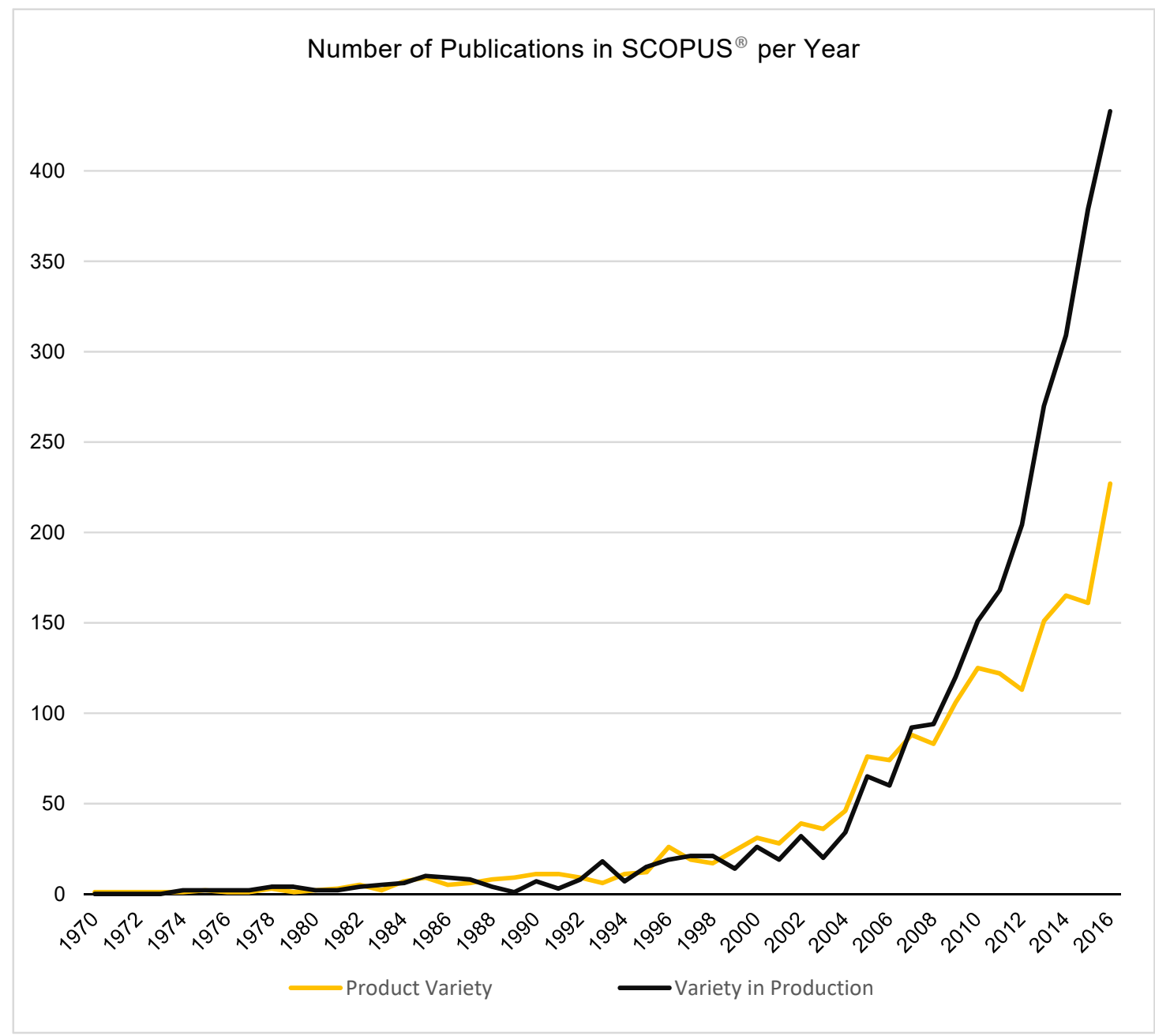

Figure 4. The number of publications per year (in SCOPUS ${ }^{\circledR}$ ) concerning product variety and variety in production respectively

\section{Discussion and conclusion}

During the product conceptual design stages, customer requirements are mapped to functional specifications on which multiple alternative design solutions are generated. Methods and tools that support collaborative conceptual design, developed for either commercial or research purposes, are rare (Wang et al., 2002). To create and develop proper methods and tools that support the conceptual modeling and assessment of multiple alternative design solutions with the influence of variety in production, the product-production variety interplay needs to be clarified. 
In this paper, variety in production is described and explained similar to product variety to serve the engineering design community with an elevated perspective of variety in production and its relation to product variety, and vice versa. A model that describes the concepts and their relation is presented.

Most research that concerns product variety and variety in production on a detailed architectural level, for example (Michaelis et al., 2015). However, no clear model that describes them on a general level was found. In this study, two sub-classes of variety in production were formed and described in the same model: production resource variety and production process variety. Concepts akin to product variety as well as variety in production was identified based on a literature review and each concept was explained of its relation to each type of variety. In addition, an analysis of past and present research related to product variety and variety in production was conducted.

\subsection{Contribution of the study presented}

The aim of this paper is to provide the engineering design community with an elevated perspective of variety in production and its relation to product variety. The contribution of this paper is: (1) a model that describes product variety and variety in production on a general level, (2) a qualitative mapping of established research concepts akin to product variety and variety in production, and (3) a trend analysis of product variety and variety in production based on the existing research.

\subsubsection{The need to see the product-production variety interplay}

In this study, the two variety concepts are made similar by separating and contrasting them; however, it is difficult to sort out product variety from variety in production and vice versa. Oftentimes, variety in production is a result of product variety; for example, without the need to satisfy a wide range of customer needs, no product variety or variety in production are needed.

Because of today's great demand for individualized products, design engineers need to be equipped with adequate support to make mutual assessments of product-production alternatives before the products are optimized. To contrast the conventional focus on product variety through the eyeglasses of marketing, engineering, and distribution, we show that different types of variety exist by themselves and in interplay. We devise that, to support the conceptual modeling, product variety and variety in production must not be separated; rather, they should be regarded as a product-production variety interplay.

\subsubsection{Research trend on product variety and variety in production}

The aim of creating two search strings was to separate the two variety concepts and illuminate the research interest of the two. Data was collected to form trend curves of the two variety concepts respectively. The most interesting observation is the fact that research on product variety and variety in production have diverged significantly during the last decade. Despite that the need for variety in production is typically driven by product variety, which is visualized in Figure 4 (years 1970-2006), the increasing interest for variety in production after year 2006 is intriguing. According to the data collected from SCOPUS ${ }^{\circledR}$, the publications concerning variety in production is almost double in number compared with the publications concerning product variety.

A few concerns regarding the results can be discussed. It is important to note that the data is collected using two search strings created based on a few keywords that supposedly can represent product variety and variety in production respectively. Most certainly there are several publications in the mass that are less linked to the two variety concepts. One needs to keep in mind that it is difficult to create a perfect search string and find the essentiality of a publication in a mass of them. Also, because a greater number of concepts related to variety in production compared with product variety were found, the search string of variety in production is longer than the one of product variety. Additionally, some concepts akin to product variety and variety in production respectively may have been unintentionally neglected.

\subsection{Future work}

Currently, there is a lack of support for engineers from both product design and production to model products and production systems mutually during the conceptual product design stages. The research presented may pave the way for future work concerning product-production variety. 
Future work will focus on the creation of approaches that can support the modeling and assessing of a product-production variety. The approaches will be developed in collaboration with industrial partners, primarily from the automotive and aerospace industries. The aim is to provide engineers from both design and pre-production with the means to develop a product variety, assess the producibility of the product variants early, as well as to support production process and resource reconfiguration; thus, supporting the development of both product variety and variety in production during the conceptual stages.

\section{Acknowledgment}

This work was carried out at the Wingquist Laboratory VINN Excellence Centre within the Area of Advance Production at Chalmers University of Technology in Gothenburg, Sweden. The research has received support from the Swedish Governmental Agency of Innovation Systems (VINNOVA) through the National Aeronautics Research Programme (NFFP7). The support is gratefully acknowledged.

\section{References}

Alizon, F., Khadke, K., Thevenot, H.J., Gershenson, J.K., Marion, T.J. et al. (2007), "Frameworks for Product Family Design and Development", Concurrent Engineering, Vol. 15 No. 2, pp. 187-199. https://doi.org/10.1177/1063293X07079326

Andreasen, M.M. (1980), Syntesemetoder Pa Systemgrundlag - Bidrag Til En Konstruktionsteori, PhD Thesis, Lund University, Lund, Sweden.

Baldwin, C. and Clark, K. (1997), "Managing in an Age of Modularity", Harvard business review, Vol. 75, pp. 84-93.

Berglund, F. and Claesson, A. (2005), "Utilising the Concept of a Design's Bandwidth to Achieve Product Platform Effectiveness", 15th International Conference on Engineering Design - ICED2005, August 15-18, Melbourne, Australia.

Boothroyd, G. (1994), "Product Design for Manufacture and Assembly", Computer-Aided Design, Vol. 26 No. 7 , pp. 505-520. https://doi.org/10.1016/0010-4485(94)90082-5

Browne, J., Dubois, D., Rathmill, K., Sethi, S.P. and Stecke, K.E. (1984), "Classification of Flexible Manufacturing Systems", The FMS magazine, Vol. 2 No. 2, pp. 114-117.

Bryan, A., Ko, J., Hu, S.J. and Koren, Y. (2007), "Co-Evolution of Product Families and Assembly Systems", CIRP Annals - Manufacturing Technology, Vol. 56 No. 1, pp. 41-44. https://doi.org/10.1016/j.cirp.2007.05.012

Choobineh, F. (1988), "A Framework for the Design of Cellular Manufacturing Systems", The International Journal Of Production Research, Vol. 26 No. 7, pp. 1161-1172. https://doi.org/10.1080/00207548808947932

Crawley, E., De Weck, O., Eppinger, S., Magee, C., Moses, J. et al. (2004), The Influence of Architecture in Engineering Systems, The ESD Architecture Committee.

Du, X., Jiao, J. and Tseng, M.M. (2001), "Architecture of Product Family: Fundamentals and Methodology", Concurrent Engineering, Vol. 9 No. 4, pp. 309-325. https://doi.org/10.1177/1063293X0100900407

ElMaraghy, H. and Abbas, M. (2015), "Products-Manufacturing Systems Co-Platforming", CIRP Annals, Vol. 64 No. 1, pp. 407-410. https://doi.org/10.1016/j.cirp.2015.04.110

ElMaraghy, H., Schuh, G., ElMaraghy, W., Piller, F., Schönsleben, P. et al. (2013), "Product Variety Management", CIRP Annals-Manufacturing Technology, Vol. 62 No. 2, pp. 629-652. https://doi.org/10.1016/j.cirp.2013.05.007

ElMaraghy, H.A. (2005), “Flexible and Reconfigurable Manufacturing Systems Paradigms”, International journal of flexible manufacturing systems, Vol. 17 No. 4, pp. 261-276. https://doi.org/10.1007/s10696-006-9028-7

ElMaraghy, W., ElMaraghy, H., Tomiyama, T. and Monostori, L. (2012), "Complexity in Engineering Design and Manufacturing”, CIRP Annals - Manufacturing Technology, Vol. 61 No. 2, pp. 793-814. https://doi.org/10.1016/j.cirp.2012.05.001

Erens, F.-J. (1996), The Synthesis of Variety: Developing Product Families, Technische Universiteit Eindhoven.

Ericsson, A. and Erixon, G. (1999), Controlling Design Variants: Modular Product Platforms, Society of Manufacturing Engineers.

Erixon, G., von Yxkull, A. and Arnstroem, A. (1996), "Modularity-the Basis for Product and Factory Reengineering", CIRP Annals-Manufacturing Technology, Vol. 45 No. 1, pp. 1-6. https://doi.org/10.1016/S0007-8506(07)63005-4

Gunasekaran, A. (1999), “Agile Manufacturing: A Framework for Research and Development”, International Journal of Production Economics, Vol. 62 No. 1-2, pp. 87-105. https://doi.org/10.1016/S0925-5273(98)002229 
Halman, J.I., Hofer, A.P. and Van Vuuren, W. (2003), "Platform-Driven Development of Product Families: Linking Theory with Practice", Journal of Product Innovation Management, Vol. 20 No. 2, pp. 149-162. https://doi.org/10.1111/1540-5885.2002007

Hu, S.J., Zhu, X., Wang, H. and Koren, Y. (2008), "Product Variety and Manufacturing Complexity in Assembly Systems and Supply Chains", CIRP Annals, Vol. 57 No. 1, pp. 45-48. https://doi.org/10.1016/j.cirp.2008.03.138

Hubka, V. and Eder, W.E. (1988), Theory of Technical Systems: A Total Concept Theory for Engineering Design, Springer, Berlin, Germany. https://doi.org/10.1007/978-3-642-52121-8

Jiao, J., Tseng, M.M., Ma, Q. and Zou, Y. (2000), “Generic Bill-of-Materials-and-Operations for High-Variety Production Management", Concurrent Engineering, Vol. 8 No. 4, pp. 297-321. https://doi.org/10.1177/1063293x0000800404

Jiao, J., Zhang, L. and Pokharel, S. (2007a), "Process Platform Planning for Variety Coordination from Design to Production in Mass Customization Manufacturing”, IEEE Transactions on Engineering Management, Vol. 54 No. 1, pp. 112-129. https://doi.org/10.1109/TEM.2006.889071

Jiao, J.R., Simpson, T.W. and Siddique, Z. (2007b), "Product Family Design and Platform-Based Product Development: A State-of-the-Art Review", Journal of Intelligent Manufacturing, Vol. 18 No. 1, pp. 5-29. https://doi.org/10.1007/s10845-007-0003-2

Johannesson, H., Landahl, J., Levandowski, C. and Raudberget, D. (2017), "Development of Product Platforms: Theory and Methodology", Concurrent Engineering, Vol. 5 No. 1, pp. 1-17. https://doi.org/10.1177/1063293X17709866

Kimura, F. and Nielsen, J. (2005), "A Design Method for Product Family under Manufacturing Resource Constraints", CIRP Annals-Manufacturing Technology, Vol. 54 No. 1, pp. 139-142. https://doi.org/10.1016/S0007-8506(07)60068-7

Koren, Y., Heisel, U., Jovane, F., Moriwaki, T., Pritschow, G. et al. (1999), "Reconfigurable Manufacturing Systems", CIRP Annals - Manufacturing Technology, Vol. 48 No. 2, pp. 527-540. https://doi.org/10.1016/S0007-8506(07)63232-6

Koren, Y., Wang, W. and Gu, X. (2016), "Value Creation through Design for Scalability of Reconfigurable Manufacturing Systems", International Journal of Production Research, pp. 1-16. https://doi.org/10.1080/00207543.2016.1145821

Krause, D. and Eilmus, S. (2011), "A Methodical Approach for Developing Modular Product Families", Proceedings of the 18th International Conference on Engineering Design (ICED2011), Lyngby/Copenhagen, Denmark.

Landahl, J., Madrid, J., Levandowski, C., Johannesson, H., Söderberg, R. and Isaksson, O. (2017), "Mediating Constraints across Design and Manufacturing Using Platform-Based Manufacturing Operations", 21st International Conference on Engineering Design - ICED2017, August 21-25, Vancouver, Canada.

Levandowski, C.E., Corin-Stig, D., Bergsjö, D., Forslund, A., Högman, U. et al. (2013), “An Integrated Approach to Technology Platform and Product Platform Development”, Concurrent Engineering, Vol. 21 No. 1, pp. 6583. https://doi.org/10.1177/1063293X12467808

Levandowski, C.E., Jiao, J.R. and Johannesson, H. (2015), “A Two-Stage Model of Adaptable Product Platform for Engineering-to-Order Configuration Design”, Journal of Engineering Design, Vol. 26, No. 7-9, pp. 220235. https://doi.org/10.1080/09544828.2015.1021305

Mehrabi, M.G., Ulsoy, A.G. and Koren, Y. (2000), "Reconfigurable Manufacturing Systems: Key to Future Manufacturing", Journal of Intelligent Manufacturing, Vol. 11 No. 4, pp. 403-419. https://doi.org/10.1023/A:1008930403506

Meyer, M.H. and Lehnerd, A. (1997), The Power of Product Platforms: Building Value and Cost Leadership, Free Press, New York.

Meyer, M.H., Osiyevskyy, O., Libaers, D. and van Hugten, M. (2017), "Does Product Platforming Pay Off?", Journal of Product Innovation Management, Vol. 35, No. 1 pp. 66-87. https://doi.org/10.1111/jpim.12378

Michaelis, M.T. and Johannesson, H. (2011), "Platform Approaches in Manufacturing - Considering Integration with Product Platforms", Proceedings of ASME DETC, Washington D.C., pp. 48275 (1115-1124). https://doi.org/10.1115/DETC2011-48275

Michaelis, M.T., Johannesson, H. and ElMaraghy, H.A. (2015), "Function and Process Modeling for Integrated Product and Manufacturing System Platforms", Journal of Manufacturing Systems, Vol. 36, pp. $203-215$. https://doi.org/10.1016/j.jmsy.2014.06.012

Oxford Dictionaries (2017), English Oxford Living Dictionaries. [online] Oxford University Press. Available at: en.oxforddictionaries.com

Prasad, B. (1996), Concurrent Engineering Fundamentals: Integrated Product and Process Organization, Prentice Hall PTR. 
Qiao, G. and Weiss, B.A. (2016), “Advancing Measurement Science to Assess Monitoring, Diagnostics, and Prognostics for Manufacturing Robotics", International journal of prognostics and health management, 7.

Robertson, D. and Ulrich, K. (1998), "Platform Product Development", Sloan management review, Vol. 39, pp. 19-31.

Rogers, G. and Bottaci, L. (1997), "Modular Production Systems: A New Manufacturing Paradigm", Journal of Intelligent Manufacturing, Vol. 8 No. 2, pp. 147-156. https://doi.org/10.1023/A:1018560922013

Rush, C. and Roy, R. (2000), "Analysis of Cost Estimating Processes Used within a Concurrent Engineering Environment Throughout a Product Life Cycle", 7th ISPE International Conference on Concurrent Engineering: Research and Applications, July 17-20, Lyon Claude Bernard University, France.

Salvador, F., Forza, C. and Rungtusanatham, M. (2002), "Modularity, Product Variety, Production Volume, and Component Sourcing: Theorizing Beyond Generic Prescriptions", Journal of Operations Management, Vol. 20 No. 5, pp. 549-575. https://doi.org/10.1016/S0272-6963(02)00027-X

Sawhney, M.S. (1998), "Leveraged High-Variety Strategies: From Portfolio Thinking to Platform Thinking", Journal of the Academy of Marketing Science, Vol. 26 No. 1, p. 54. https://doi.org/10.1177/0092070398261006

Schachinger, P. and Johannesson, H.L. (2000), "Computer Modelling of Design Specifications", Journal of Engineering Design, Vol. 11 No. 4, pp. 317-329. https://doi.org/10.1080/0954482001000935

Simpson, T.W. (1998), A Concept Exploration Method for Product Family Design, PhD Thesis, School Mechanical Engineering, Georgia Institute of Technology, Atlanta, USA.

Simpson, T.W., Siddique, Z. and Jiao, J.R. (2006), "Platform-Based Product Family Development", In: Simpson T.W., Siddique Z. and Jiao J.R. (Eds.), Product Platform and Product Family Design, Springer, pp. 1-15. https://doi.org/10.1007/0-387-29197-0 1

Tolio, T., Ceglarek, D., ElMaraghy, H.A., Fischer, A., Hu, S.J. et al. (2010), "Species - Co-Evolution of Products, Processes and Production Systems”, CIRP Annals - Manufacturing Technology, Vol. 59 No. 2, pp. 672-693. https://doi.org/10.1016/j.cirp.2010.05.008

Ulrich, K. (1995), "The Role of Product Architecture in the Manufacturing Firm”, Research Policy, Vol. 24 No. 3, pp. 419-440. https://doi.org/10.1016/0048-7333(94)00775-3

Wang, L., Shen, W., Xie, H., Neelamkavil, J. and Pardasani, A. (2002), "Collaborative Conceptual Design-State of the Art and Future Trends", Computer-Aided Design, Vol. 34 No. 13, pp. 981-996. https://doi.org/10.1016/S0010-4485(01)00157-9

Wheelwright, S.C. and Clark, K.B. (1992), Revolutionizing Product Development: Quantum Leaps in Speed, Efficiency, and Quality, Simon and Schuster.

Jonas Landahl, PhD Candidate

Chalmers University of Technology, Industrial and Materials Science

Hörsalsvägen 7A, 41296 Gothenburg, Sweden

Email: jonas.landahl@chalmers.se 